\title{
Urban water supply infrastructure in Grudziądz (northern Poland): from the Middle Ages to the pre-modern times
}

\author{
Wacław Kulczykowski ${ }^{1}$ (D)
}

Received: 14 June 2020 / Accepted: 14 December 2021 / Published online: 13 January 2022

(c) The Author(s) 2022

\begin{abstract}
This article presents the history of the water supply system in Grudziądz (Poland) over the centuries, from the Middle Ages to the end of the nineteenth century. The location of Grudziądz on the high escarpment of the Vistula River made it difficult to supply water to the town. The innovative technical facilities, such as a water-work and water supply tower had to be constructed because the gravitational waterworks could not be applied. The basis for the research was the analysis of historical sources. In this study, non-invasive methods were used (aerial prospection, LiDAR scanning and geophysical surveys with Ground Penetrating Radar), since the hydrotechnical objects are located in a functioning urban space and no excavations could be carried out. The research included: (i) the measurements, exploration and preparation of photo-documentation of the water tower, (ii) providing a digital model of the tower, (iii) finding the tunnel inside the tower, and (iv) attempting to locate the tunnel's course outside the tower.
\end{abstract}

Keywords Urban history · Waterworks · Water management · East-Central Europe · Medieval $\cdot$ Pre-modern period

\section{Introduction}

In the Middle Ages, Grudziądz (Poland) was an important town on the Vistula trade route between Torun and Gdańsk due to its favorable location on the Vistula waterway. One of the basic conditions for the functioning of every city is supplying water for the needs of its inhabitants: for domestic use, fire protection, and commercial industries such as brewing. Though it was on the river, Grudziądz was located on the high escarpment of the Vistula River, ranging from $15 \mathrm{~m}$ (the southern, lower part of the town) to $31 \mathrm{~m}$ (the Teutonic castle) above river level, which made it difficult to supply water to the town. In the Middle Ages, the development of the town together with the growing number of inhabitants generated increasing demand for water and consequently, a problem with its supply. One of the main prerequisites for the development of a city is access to fresh water. Therefore, numerous modern (by European standards) technical solutions were employed to feed water

Wacław Kulczykowski

waclaw.kulczykowski@ug.edu.pl

1 Faculty of History, University of Gdańsk, ul. Wita Stwosza 55, 80-308 Gdańsk, Poland 
directly to the town. There were long water canals and municipal waterworks, including probably the first Wasserkunst (mechanism transferring the water to a higher level) in the Teutonic state.

The idea of municipal waterworks was nothing new: in the fourteenth century, other towns in the State of the Teutonic Order already had their own systems of water distribution. The operation of gravitational waterworks distributing water through wooden pipes has been confirmed in three towns in Poland. A permit issued to the town of Elbag in 1275 by Grand Master Konrad von Thierberg allowed the town to draw water from the Kumiela River channel through a drilled five-inch diameter pipe (Woelky and Saage 1860; Sowina and Kulczykowski 2017). Toruń and Gdańsk also had wooden pipes in the fourteenth century (Kola et al. 2005; Maciakowska 2011). The water supply systems in these two large commercial centres Torun and Gdańsk, probably followed the model of waterworks of Lübeck constructed in the late thirteenth century. This is likely, because the extensive trade contacts in the Hansa region and frequent visits of the Teutonic Knights in the Hansa towns have been confirmed (Sowina and Kulczykowski 2017).

The aim of this article is to present the history of the water supply system of the town of Grudziądz over the centuries, from the construction of the first, medieval municipal waterworks to the modern water distribution system at the end of the nineteenth century. Grudziądz is a good example of a town where a number of innovative technical solutions have been applied over the centuries. Despite this, its water supply system has never been studied before, even though the water supply system in Grudziądz was continually modernized over the centuries until the end of the nineteenth century when modern municipal waterworks were built. The current state of research on water supply problems in various European towns from the Late Middle Ages to the early modern period, including towns located at rivers, has been quite recently summarized (Sowina 2016) so that it is not described in detail here. What is important to note, however, is that the development of urban hydrotechnical infrastructure in the cities of Central and Eastern Europe over the centuries is still a neglected topic in academic research and almost absent from international scientific literature. Therefore it is time to change this.

\section{Study area}

Grudziądz (Fig. 1a), a town founded by the Teutonic Order in 1291, is located in the northern part of Poland on the high escarpment of the Vistula River (Fig. 1b) and surrounded by wetlands. Until 1386, the main water source for the town was the River Osa flowing north of Grudziądz; its southern branch flowed into Lake Tuszewskie located to the east of the town. From this lake, via a mill canal built near the southern part of the town, water was drawn by the inhabitants or delivered to the town by barrels (Fig. 2). Over time, the expansion of the network of drainage ditches to the east of the town resulted in gradual drainage of the area, and the shallow Lake Tuszewskie began to dry out. The town's inhabitants and the authorities of the Order saw the danger of diminishing drinking water resources and began to look for alternative sources of water. In 1386, the town authorities decided to build a canal, which was connected to a natural stream flowing out of Węgrowo, a village located about $5 \mathrm{~km}$ southeast of Grudziądz, to increase water supply to the mill canal near the town (Froelich 1868).

Due to the town's location on a high escarpment, the construction of intake wells, common in other cities in the State of the Teutonic Order in Prussia, would have been 


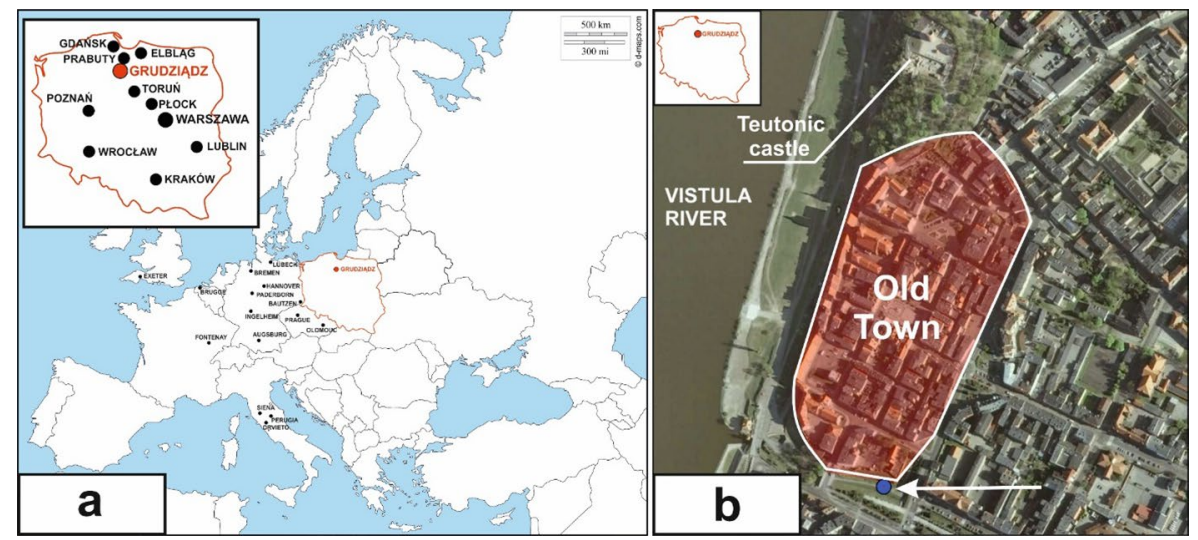

Fig. 1 a Location of Grudziądz and other towns mentioned in the study. Source https://d-maps.com/carte. php?num_car=2232\&lang=en. b Satellite image of Grudziądz with the Old Town marked. The spot indicates the location of the water-raising device. The approximate area of the Old Town is 8 ha. Source Google Earth and https://dmaps.com/carte.php?num_car=2232\&lang=en

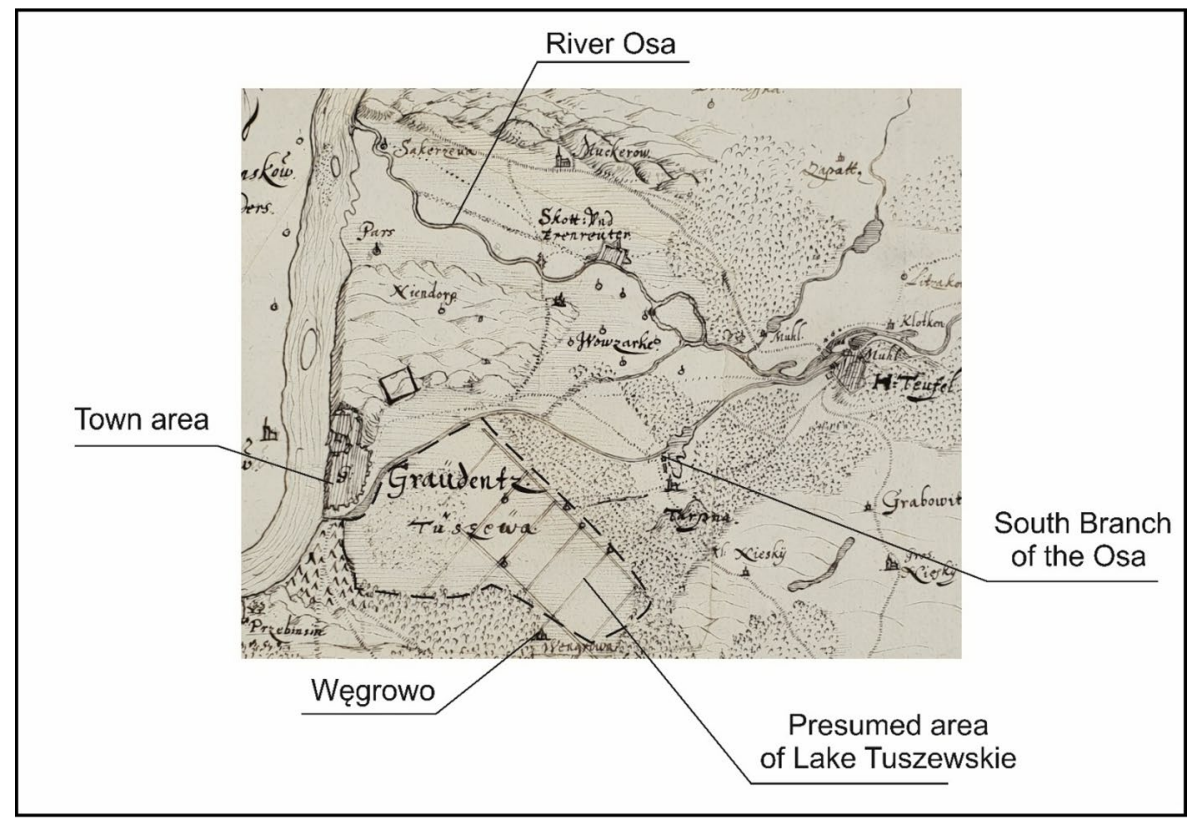

Fig. 2 Fragment of a map of Grudziądz and its environs by Olof Hansson Örnehufvud from 1628. Osa River, town of Grudziądz, the presumed area of Lake Tuszewskie (dashed line) and Węgrowo, the village from where the canal was laid in 1386, are marked. Source SE/KrA/0425/01/151

an expensive and time-consuming solution. Indeed, no remnants of any wells have been found inside the town walls (Kurzyńska 2016); but this does not exclude their presence. Taking water directly from the mill canal and transporting it in barrels was inconvenient and impractical. Therefore the need arose to apply innovative technical solutions, including 
modern waterworks. It is also obvious that location of Grudziądz high above drinking water resources excluded application of the classic waterworks with a gravitational water drop from the place of intake to the place of distribution. Therefore, inside the building, a special device transferring the water to a higher level was required (a 'water-work', kunszt wodny [Pol.]; Wasserkunst [Ger.]). The permit to build a 'water-work' with such a device was issued to citizens of Grudziądz by the Grand Master of the Order on 24 May 1415 (Froelich 1868).

It should be stressed here that the old Grudziądz water supply system is only partially preserved and historical sources are scarce. The water tower adjacent to the medieval southern town walls is one of the best-preserved remnants of this system, but it has not been investigated prior to this study. Indeed, the excavation works in the town and its surroundings were limited to archaeological compliance and rescue excavations (summarized by Kurzyńska 2016) and did not include the water distribution system. However, during reconstruction of streets and buildings in the town, a few artefacts related to the water supply infrastructure have been found, such as individual wooden pipe fragments, connected with metal fittings (found in 1961 and 1974) (Sikorska 1961; Boguwolski 1974) and a brick well at the back of the lot at 18 Szewska Street (found in 1974) (Boguwolski 1974-1975). During the excavation carried out at the Grudziądz Teutonic Order castle on Góra Zamkowa in 2008-2009 the remnants of the historic well and a drainage system removing excess water from the castle were exposed and reconstructed (Wiewióra 2012).

\section{Methods}

Since the former hydrotechnical objects in Grudziądz are located in a functioning urban space, in a zone covered by conservator's protection, conducting excavations or using any invasive methods is impeded or impossible. Hence the need for an interdisciplinary approach and non-invasive field research, such as exploration of the preserved hydrotechnical objects, use of aerial prospecting, geophysical surveys of the ground, and preparing photographic and digital documentation. The basis for the research was the analysis of available historical sources (written, cartographic, and iconographic) and data from scarce excavations in Grudziądz and its surroundings. It is for this reason that interpretation of the results had to be based on comparative analysis of data from various archaeological studies in similar European cities.

During the research, many non-invasive surveys were carried out in collaboration with teams of Scan 3D (aerial prospection-UAV, LiDAR scanning) and GeoSearch System (ground penetrating radar-GPR). In 2016, there were conducted measurements and exploration of the interior of the water tower, the only well-preserved part of old Grudziądz water supply system, followed by aerial prospection (UAV) of the tower and its surroundings in 2017. For this purpose, a multi-rotor drone with a remotely controlled camera was used. At the same time the photo-documentation of the tower was prepared.

In 2017, LiDAR scanning of the water tower's exterior and interior as well as that of the surrounding area was performed. The measurements were carried out using a Faro Focus $3 \mathrm{D} \times 130$ laser scanner with an accuracy of 1 point $/ \mathrm{mm}^{2}$. As a result, a precise digital model of the tower was obtained in the form of a dense point cloud with a real and coloured texture (Fig. 3). Two variants of this model were developed: a version using the CAD digital architectural model (Fig. 4a) and a version with a mesh structure (Fig. 4b). Moreover, the spatial measurements were referred to the geodetic reference system (PL2000 system). 


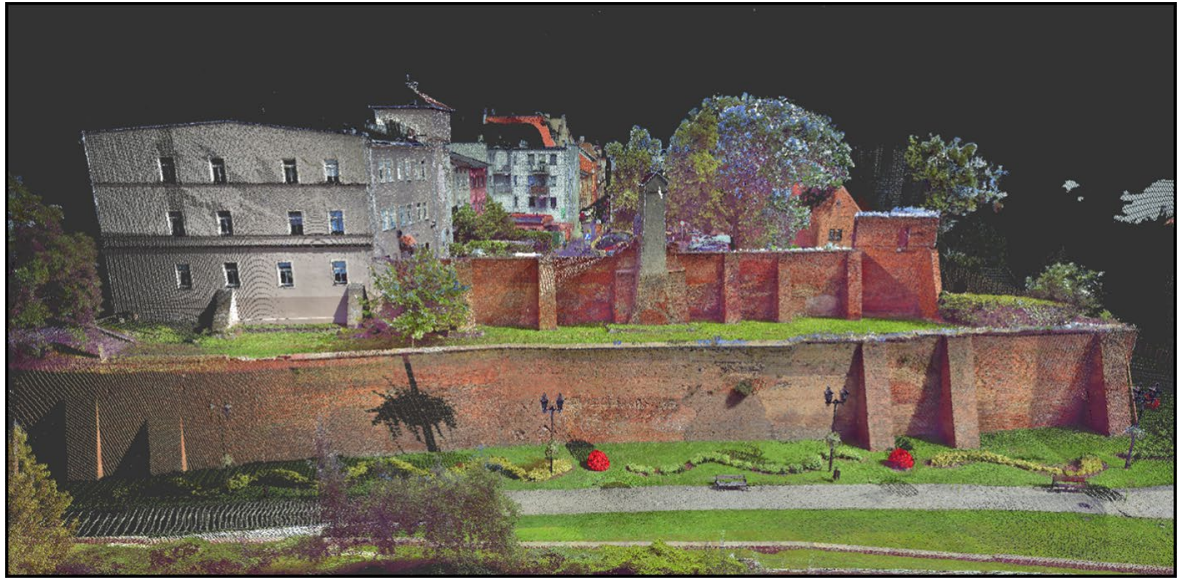

Fig. 3 Digital model of a fragment of the southern section of the town wall in Grudziądz with the water tower (point cloud)
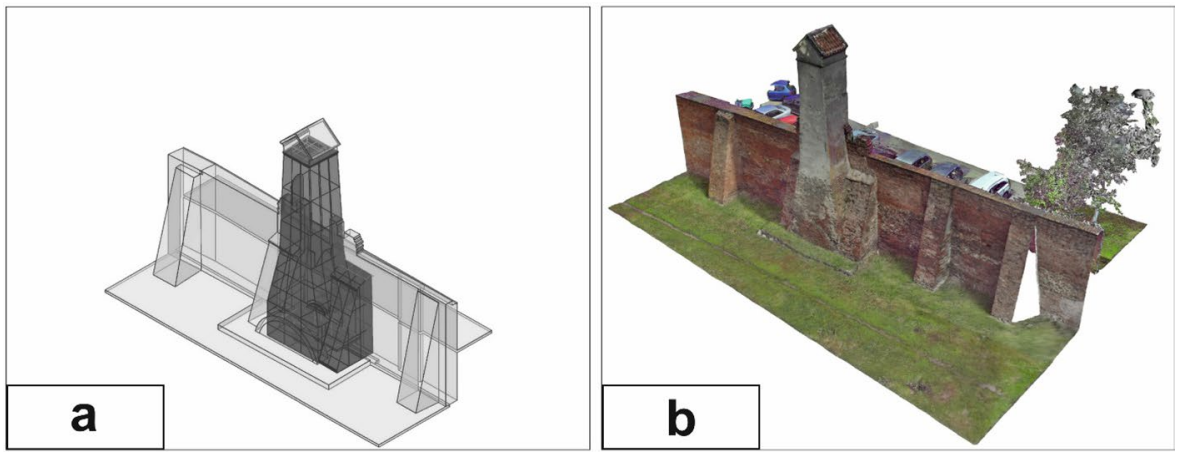

Fig. 4 a CAD digital architectural model of the water tower in Grudziądz. b Digital mesh model of the water tower mesh in Grudziądz (textured view)

High resolution visualizations and animations were also made. Both were very useful for the presentation of the results. LiDAR scanning is a modern method that is widely used to prepare precise, digital documentation of architectural objects and archaeological sites. It is not only much faster and more accurate than drawing, but also allows data collection, processing, and visualization on the basis of GIS (Geographic Information System) software, creating a database for further analyses (Previtali, Valente 2019).

In 2019, geophysical surveys of the ground in the vicinity of the water tower were carried out using GPR. The method consists in the emission by the device of an electromagnetic wave towards the ground and registration of its reflection from objects located underground. Due to building density, such studies could only be carried out on the parking lot adjacent to the tower (dimension of $21 \times 25 \mathrm{~m}$ ). The surface of the site was heavily cracked, which could indicate the presence of a scattered material in the ground under the surface. The survey was carried out with Acula 9000C geo-radar (Geoscanners) combined with a $300 \mathrm{MHz}$ antenna. The recording time was set at $120 \mathrm{~ns}$, which in combination with the assumed speed of electromagnetic wave propagation $\mathrm{V}=0.055 \mathrm{~ns} / \mathrm{m}$ allowed penetration 
of the ground to the depth of about $3.30 \mathrm{~m}$ (due to multiple forms of interference the resolution in practice reached about $2.10 \mathrm{~m}$ ). The data was processed using GPRSoft Pro, ReflexW, GPR Slice and Surfer11 for interpretation of the results.

\section{Results}

\section{The water supply system in the light of historical research}

Historical sources state that a permit for the construction of the water supply system in Grudziądz was issued to citizens of Grudziądz by the Grand Master of the Teutonic Order Michael Küchmeister on 24 May 1415. The approval included construction of the building with a special device equipped with a water wheel. The building was to be located by the mill canal, at the southern town walls (Fig. 1b) (Froelich 1868). Until then, the canal had three functions: it provided drinking water near the town, drove mill wheels, and served as the southern moat for the town. The device mentioned in the permit was to draw water from the mill canal and raise it to the appropriate height and called a 'waterwork' (German: Wasserkunst). However, there are no descriptions, drawings, or any data on technical details of the water-work in Grudziądz in the fifteenth century. Usually, this was a tall building, located near a watercourse (river, moat, canal, etc.), with a drawing or pumping mechanism inside and a distribution tank on the top. The main driving element in the device was usually the water wheel. This wheel was connected, by means of a gearbox, with a second wheel, a bucket wheel, taking water from the canal and lifting it to the appropriate height to the distribution tank. In such works, water from the distribution tank was fed into the water pipes and distributed gravitationally to the municipal collection points. There were intermediate and final water supply wells (water storage reservoirs). If the water-work in Grudziądz was built in the fifteenth century, it is likely that a mechanism with buckets was also installed here, similarly to that described in other water-works (Sowina 2016; Cembrzyński 2011; Grewe 2000; Grabowski, Mührenberg 1994). In this case, it would be the first, water-work in the State of the Teutonic Order, attested by sources, and one of the oldest in the Kingdom of Poland.

The water supply infrastructure in Grudziądz was marked on maps, including the earliest and most precise map by Loffman from 1657, which showed the location of the waterwork (Fig. 5, Kriegsarchiv Stockholm). According to the map, a role of the water-work with a water wheel was to transport water to the tower (Wasserkunst, welche durch ein radt das wasser auffm Thurm), from where it was distributed around the town (und von das in die Stadt treibt). The general description given by Loffman suggested that the water raising device was located in the tower with the distribution tank, directly next to the town walls. There was a place where water was introduced by pipes into the town and then distributed to the water wells. Loffman marked five places where such wells were located (Springk thorn und Wasser behalter). The first two wells were located in the southern part of the town: one near the Torun Gate and today's Klasztorna Street, and one at the intersection of Klasztorna Street and today's Szkolna Street. The third well was located on the market square, opposite the town hall and was probably the only one covered and equipped with a street pump. It was depicted as a manual street pump on the map of Grudziądz from 1650 to 1659 , on which Loffman likely based his own (Fig. 6). The other two wells were located in Długa Street and Staronkowa Street. It should be noted that all public wells in Grudziądz marked on Loffman's plan from 1656 (Fig. 5) were situated in the urban space, 

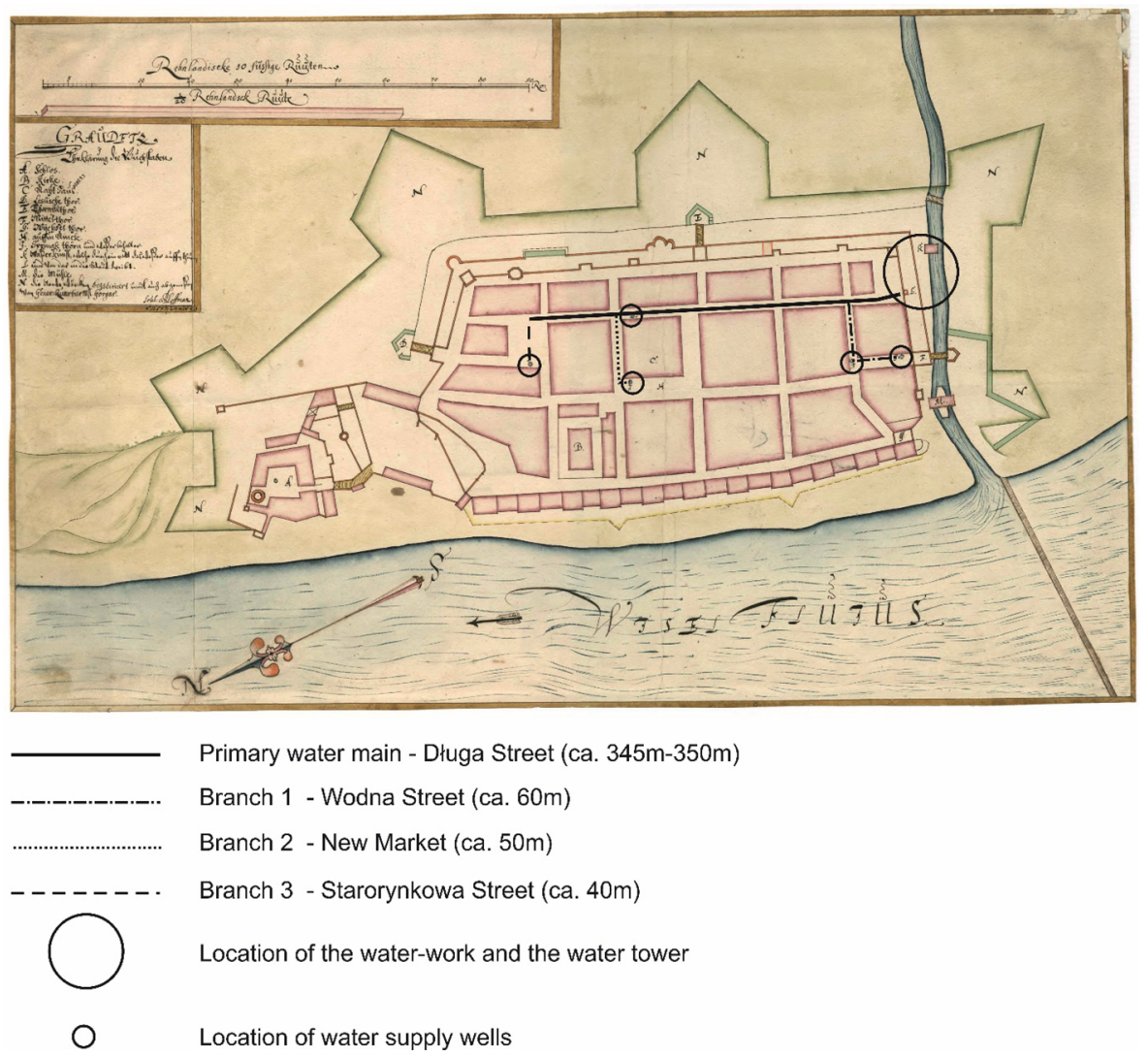

Fig. 5 Map of Grudziądz from 1657 by Loffman. The map shows the location of the water-work, the water tower, and the town's water wells. The black lines mark the presumed layout of the sixteenth-century water supply system in Grudziądz. Source Kriegsarchiv in Stockholm, SE/KrA/0425/06/010

at wide street crossings or squares. Such locations offered residents easy access to drinking water, and during a fire, improved the fire-fighting process. Additionally, near the wells were placed commercial buildings, such as city breweries or malt houses, which required a constant supply of water.

In 1656, Erik Dahlberg, a Swedish military engineer and specialist in the construction of field fortification, who was taking part in the military campaign in Poland in the years 1655-1660, drew a panorama of Grudziądz and depicted the "town waterworks" (Fig. 7). The term Aqueductus refers to a building east of the southern town gate (Torun Gate), which was higher and narrower than the gate tower. On the panorama, "town waterworks" has the form of a tower with two rows of windows and a sloping roof with one window in the attic. However, it should be noted that most of the two-storey buildings in Grudziądz were presented by Dahlberg in a very similar manner, suggesting that the author drew the buildings schematically.

More information about the appearance and functioning of Grudziądz's water-work and water tower comes from the turn of the nineteenth century. Two pieces of evidence are Ludwig von Baczko's reports of his travels through Prussia in 1800 (Baczko 1800) and 


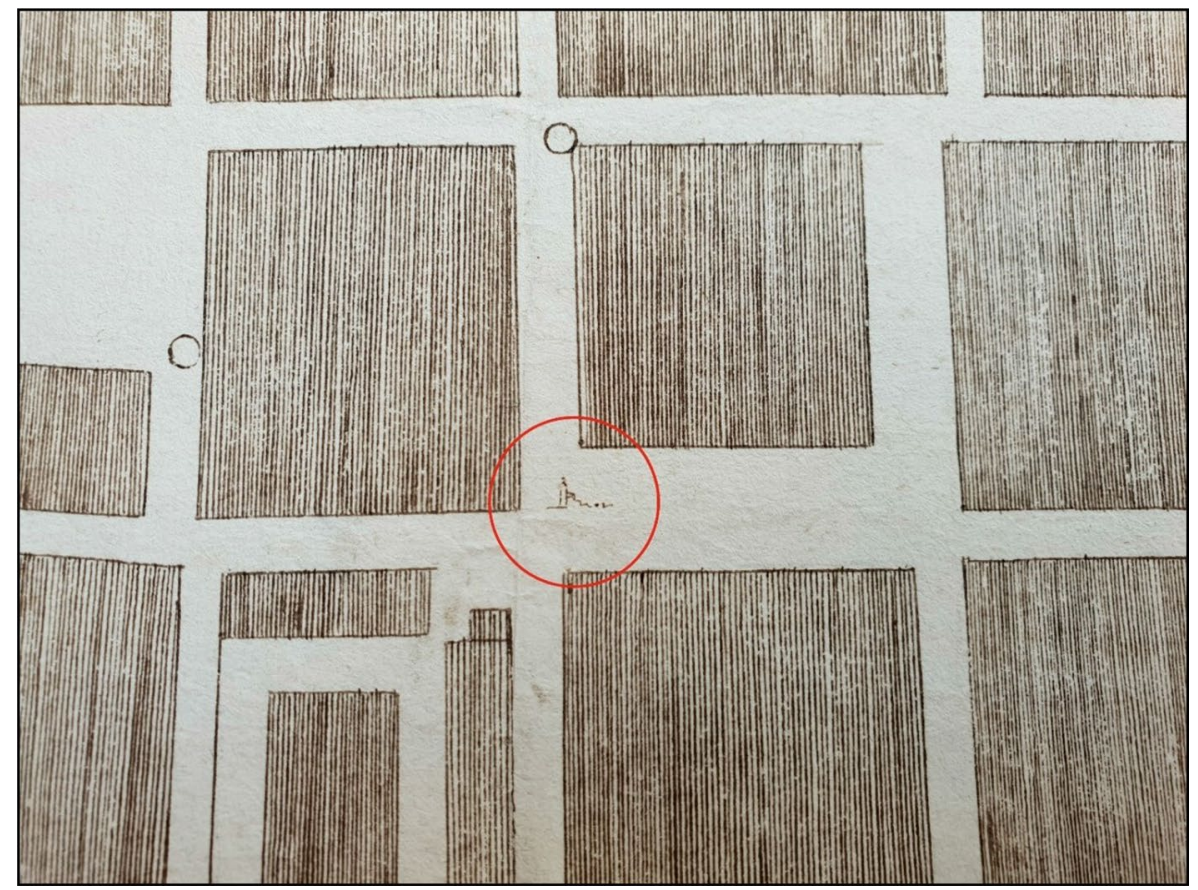

Fig. 6 Fragment of a map of Grudziądz from 1650 to 1659. The street pump opposite the town hall is circled in red. Source Riksarkivet Marieberg in Stockholm, SE/RA/754/2/XV/ /0005:00001

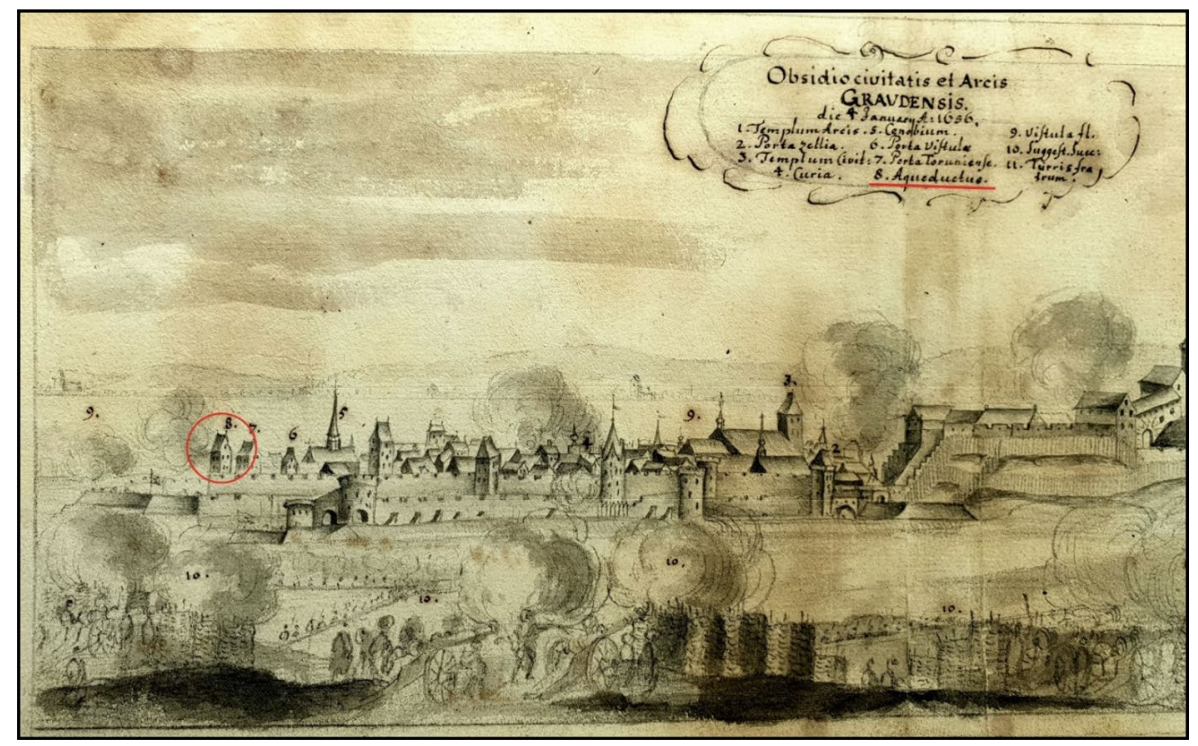

Fig. 7 Panorama of Grudziądz from 1656 by E. Dahlberg. The location of the tall building associated with the town's water supply (Aqueductus) is circled in red. Source Riksarkivet Marieberg in Stockholm, SE/ RA/720269/\#/0041:00001 
archival technical plans (State Archives in Torun, files of the City of Grudziądz, reference number 448). These documents showed that at that time the water-work consisted of two buildings, presented schematically in the drawing (Fig. 8). The first oblong, one-storey building was erected on a wooden platform set on piles, directly over the mill canal. Underneath this building, the watercourse was divided into two channels: a southern relief channel, with an adjustable weir, and a northern channel leading water to the backhoe water wheel located inside this building. The second, two-storey building, was located on the northern bank of the mill leat and adjoined the first building in the water wheel zone. On

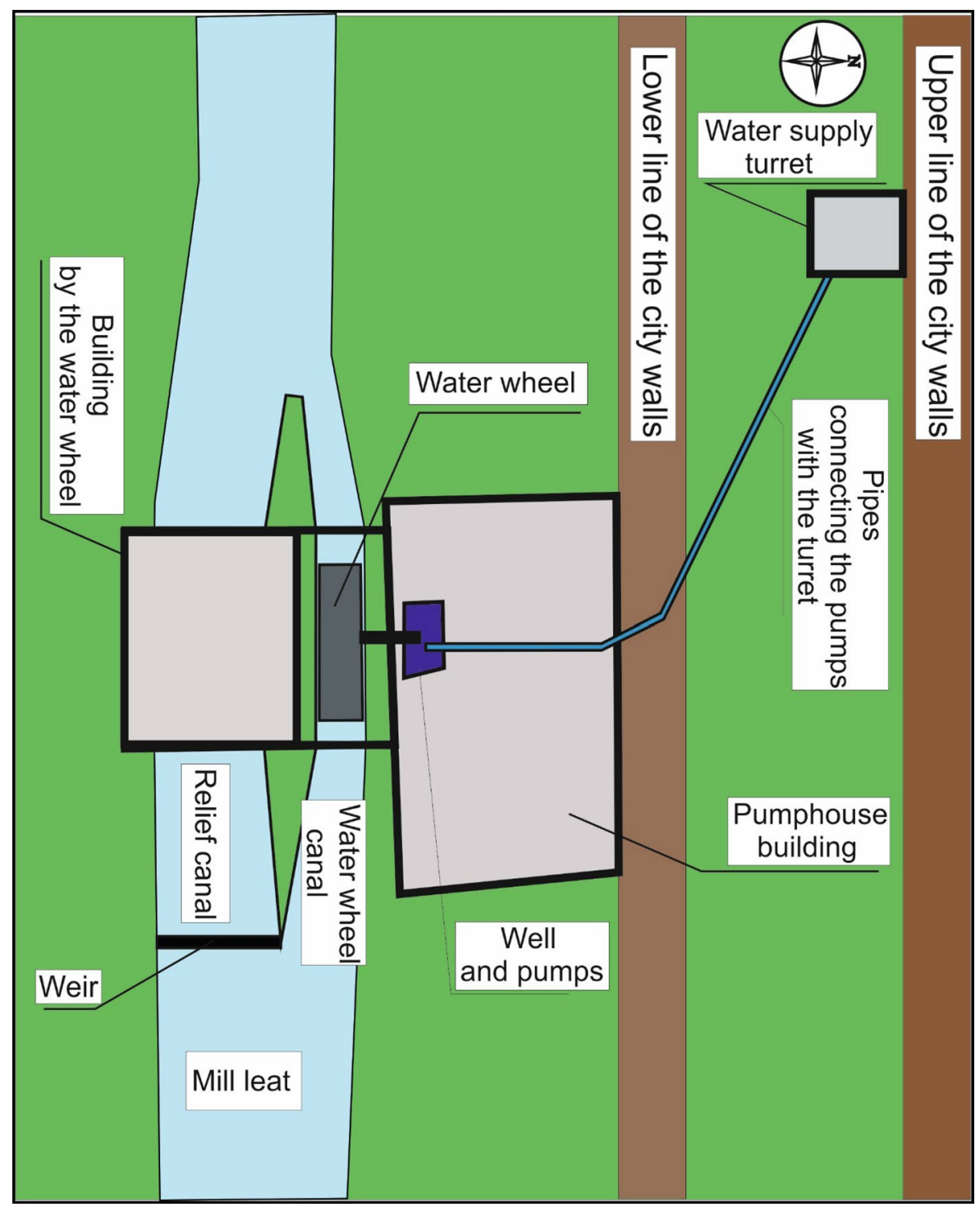

Fig. 8 Illustrative sketch of the water-work in Grudziądz based on a drawing from 1800 
the ground floor of this building, there was a two-cylinder pump, which was driven by the waterwheel through a crankshaft. Two alternately moving pistons sucked water from a well located directly under the pump. While the water was being sucked in, a non-return flap valve opened up in the pump to let water into the pump cylinder. After the cylinder was filled, the piston fell down, the non-return valve closed, and water was pressurised into a system of metal and wooden pipes, and thereby transferred from the water-work to the water tower which was situated close to the town walls (see Fig. 8).

The water supply tower was a separate building located on the upper line of the town walls, a dozen or so meters northwest of the water-work. In the upper part of the water tower, there was most probably a reservoir, from which water was distributed gravitationally through the town. The pipeline from the water-work to water tower was most probably routed underground to prevent water from freezing (the temperature in winter in this region is below $0{ }^{\circ} \mathrm{C}$ ). Ludwig von Baczko supposed that the tower was built to allow a fire to be lit inside to prevent water from freezing in the pipes and the distribution tank. It can be assumed that the construction described above was present in Grudziądz as early as sixteenth century, because some elements in the tower, such as Gothic bricks in the lower part of the building, have testified to its medieval origin. It is worth mentioning that a system of water intake and distribution, consisting of the separate buildings, a water-work with a pumping mechanism at the mill canal and a water supply tower with distribution tank was present in several European cities (please see "Discussion" section).

In the second half of the nineteenth century, a new hydrotechnical solution began to spread in Europe. It consisted in the water supply and sewage disposal systems combined into one centralized system. At the end of the nineteenth century, the municipal authorities ordered examination of the abundance of groundwater in Grudziądz. As a result, rich resources of drinking water in the southern part of the town, in the vicinity of the town forest and today's Gen. J. Haller Street, were discovered and modern, urban waterworks planned (Chmielewski 1999). Waterworks with deep water wells and pumps driven by steam engines were put into operation on 23 December 1899 and at the beginning of twentieth century they were complemented with a sewage network and sewage treatment plants. In 1905, waterworks were purchased from the town by the owner of the Lower and Upper Mills for 5000 marks (Fischer 1906).

\section{Non-invasive field surveys}

The water tower located at the southern town walls as a part of the fortification is the only well-preserved object testifying to the existence of the former Grudziądz water supply system (Fig. 9a). The historic water tower is a tall, brick building covered with a gable roof. At its base, on the southern side, there is an inlet with an arched vault, currently walled up. This unique hydrotechnical structure has not been studied to date.

Exploration of the tower's interior has shown that it is free of any constructions, pipes or tanks (Fig. 9b). The whole bottom of the shaft is filled with debris reaching up to the upper part of the vault of the bricked-up inlet. A hole with an arched vault located opposite the bricked-up inlet was discovered during the survey (Fig. 9c). It is most probably the beginning of an underground water supply tunnel, through which water was distributed through the town. A part of the tunnel of about $1.5 \mathrm{~m}$ length from the inlet of the tunnel has been preserved. Gothic brick (handmade, characteristic of the medieval period, measure circa $28 \times 13 \times 7 \mathrm{~cm}$ to $30 \times 14 \times 9 \mathrm{~cm}$ ) was used to build the water supply tunnel. It is worth noting that both the outer arch (inlet to the tower) and the inner 

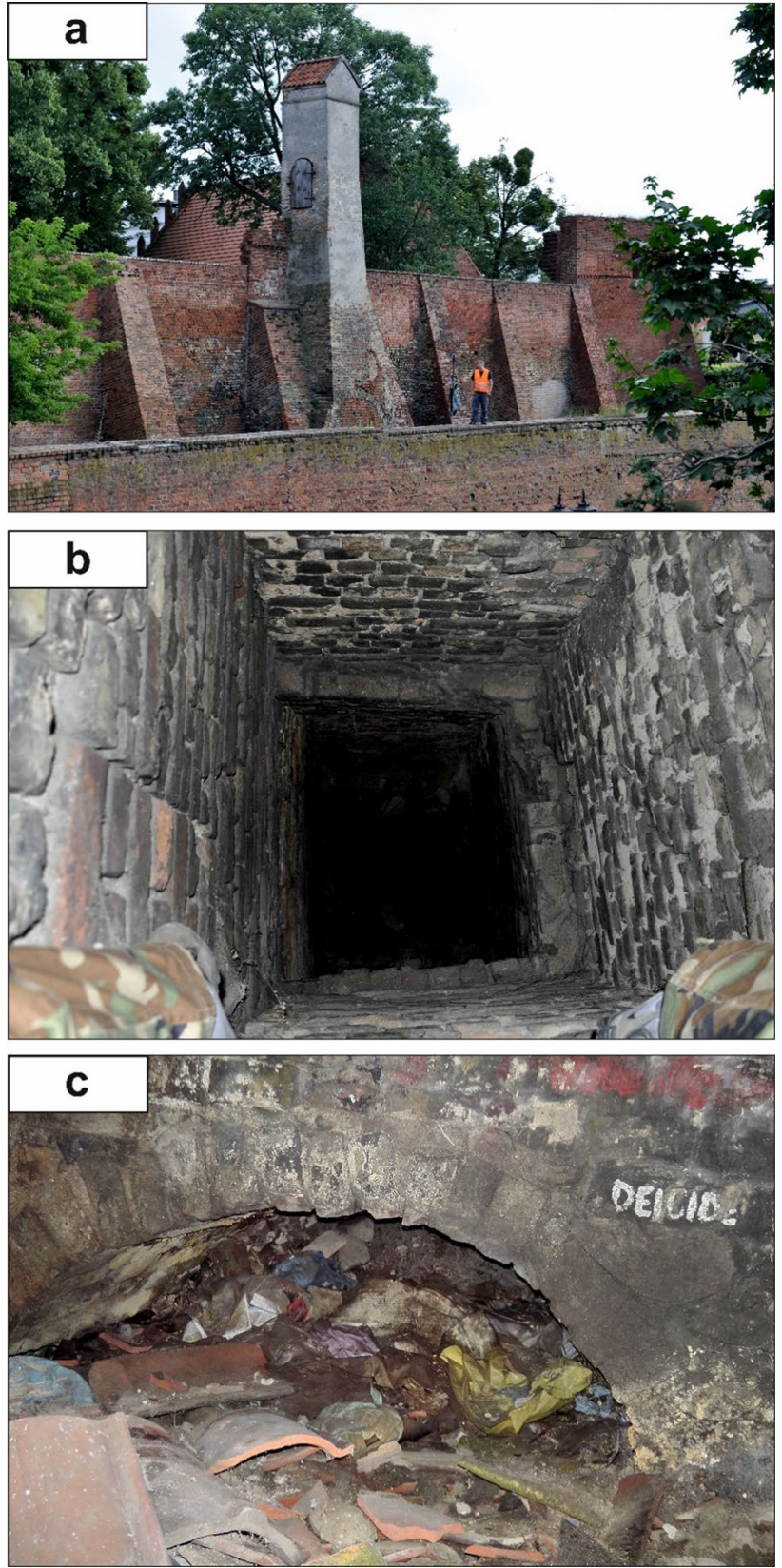

Fig. 9 a Water tower in Grudziądz. Photo: W. Kulczykowski. b Water tower shaft (top view). Photo: W. Kulczykowski. c Inlet to the collapsed water supply tunnel located in the northern wall of the tower. Photo: W. Kulczykowski 
arch (inlet to the tunnel) were made in full-arch construction, which was typical for the Renaissance period (starting in the sixteenth century).

Further examination of the water tower began with an aerial survey (UAV) to photograph and make a video of the spatial layout of the entire surveyed area, i.e., the southern moat, urban fortifications and water tower. The UAV is frequently used to document construction details which are invisible from the ground surface, as is the case for the water tower. The second purpose of the survey was to identify a probable location of the past water-work (it longer exists). Given a complete picture of the southern part of the Old Town, showing the water tower and city walls, the location of water-work can be estimated.

The LiDAR scanning included the exterior and interior of the water supply tower and the area around the tower, covering a fragment of the southern section of the town walls, from the southern town gate to the south-eastern corner tower. Analysis of the digital cloud of measurement points provided data for digital documentation of the entire water supply tower and the area around it, including a fragment of the southern section of the town walls. The tower is $12.8 \mathrm{~m}$ high, measuring from the base to the top of the roof. Its width is $4.27 \mathrm{~m}$ at its widest point at the base, and $1.77 \mathrm{~m}$ at its narrowest point (including the "protruding" part of the vault of the tunnel inlet but not including the buttresses). The distance between the southern wall of the tower and the town walls, measured at its base, is $1.98 \mathrm{~m}$.

The bricks in the lower part of the building are arranged in a Venetian bond, which was used starting in the sixteenth century. However, above the height of the crown of the town walls the English bond dominates. The tower, which is an element of the town fortifications, was exposed to damage. Since it has probably been repaired and rebuilt many times, this makes it difficult to determine the time of its creation based on brick bonds. The construction of the tower at ground level is bordered by a stone step. Above the former inlet, in the wall of the tower, there are the outlines of a small hole, now bricked up.

On both sides of the tower, there are brick buttresses, reinforcing both its construction and the town walls, in which the tower is integrated. From the half height of the buttresses ( $2.35 \mathrm{~m}$ from their base), the width of the tower begins to decrease and at a height of about $5.10 \mathrm{~m}$ from the base it measures $2.15 \mathrm{~m}$. From this point on, the tower has the shape of a narrow chimney with a now unchanging width.

The upper part of the tower is plastered and at its top the walls are surrounded by a narrow, decorative orifice. The two-tiered roof is covered with tiles. In the attic area, at a height of $7.80 \mathrm{~m}$ from the base, there is an entrance opening in the western wall, measuring $0.85 \mathrm{~m}$ wide and $1.66 \mathrm{~m}$ high, closed with a wooden door. The tower is adjacent to the town defensive walls and fitted into a preserved fragment of a crenellation, which further stabilizes the structure at this point. In the lower part of the tower, the thickness of its walls (with the exception of the northern wall, which is partly made up of the town wall) is about $45 \mathrm{~cm}$ (the header, the stretcher and the thickness of the mortar). From the upper part of the structure the thickness of the above three walls is reduced to $28-30 \mathrm{~cm}$, i.e., to the length of a Gothic brick. The thickness of the northern wall above the height of the town wall is the same as the thickness of the crenellation and is about $45 \mathrm{~cm}$. The height difference between the water intake point (the well located at the water-work) and the presumed location of the distribution tank (at the top of the water tower) was $23.5 \mathrm{~m}$. Therefore, the water had to be raised by the pumps to such a height.

The following data have been collected as a result of exploration and LiDAR scanning of the interior of the tower:

(a) the thickness of the rubble layer at the bottom of the water tower shaft: $1.11 \mathrm{~m}$ (Fig. 10); 


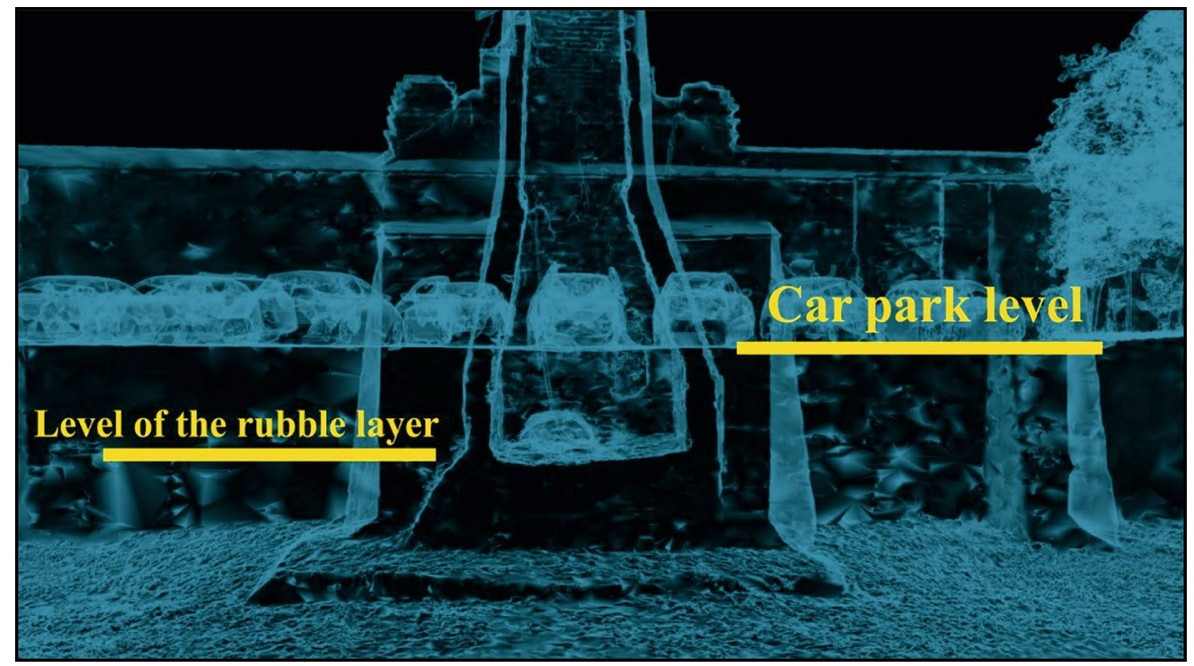

Fig. 10 Digital mesh model of the water tower in Grudziądz. The image shows the rubble layer on the bottom of the tower in relations to the level of car park (X-ray view)

(b) internal dimensions at the bottom of the backfilled shaft: $2.76 \mathrm{~m}$ width; $1.85 \mathrm{~m}$ depth (ca. $\left.5.10 \mathrm{~m}^{2}\right)$;

(c) internal dimensions of the unfilled, visible part of the water supply tunnel with arched vault: width $1.25 \mathrm{~m}$; height $0.42 \mathrm{~m}$; length $1.46 \mathrm{~m}$ (Fig. 11);

(d) the course of the water supply tunnel: northward (perpendicular to the defensive walls), at the depth: $1.28 \mathrm{~m}$ under the surface of the ground (currently a car park) located behind the tower, on the inside of the walls. The above course of the backfilled water supply tunnel coincides with the depression of the surface of the car park.

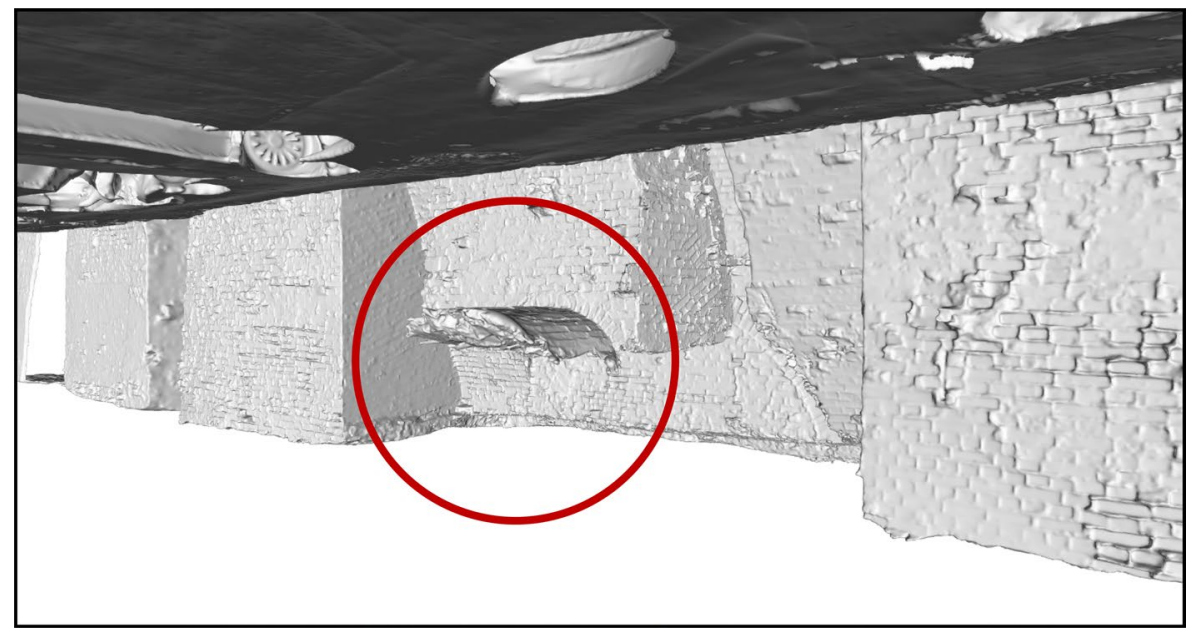

Fig. 11 Location of the part of the water supply tunnel discovered in the course of research (mesh model, solid view) is circled in red 
In order to determine the course of water supply tunnel on the inside of the walls, additional examinations have been performed. Because the surveyed area (Old Town) is covered by conservator's protection, it is not allowed to carry out any invasive surveys of the ground (excavating, drilling, or probing). Therefore, geophysical surveys of the ground by GPR have been conducted. It had been expected that the GPR data could indicate the probable course of the water supply tunnel. However, in this case, the GPR records did not give any conclusive results. Indeed, the GPR images do not always allow identification of objects underground (appearing as some anomalies in the GPR record) (Karczewski 2007). On the other hand, taking together the results of field studies, localization of wells (archival plans), and GPR records, it can be assumed that the tunnel run in a northerly direction, with a slight deviation to the east, toward the centre of historic Grudziądz (Fig. 12).

\section{Discussion}

It can be assumed that the Grudziądz water-work builders followed the example of other water supply systems and implemented technical solutions known in Europe. Regrettably the old Grudziądz water supply system is only partially preserved and historical sources are scarce. Therefore the interpretation of results was based on comparative analysis of data from studies in other European cities.

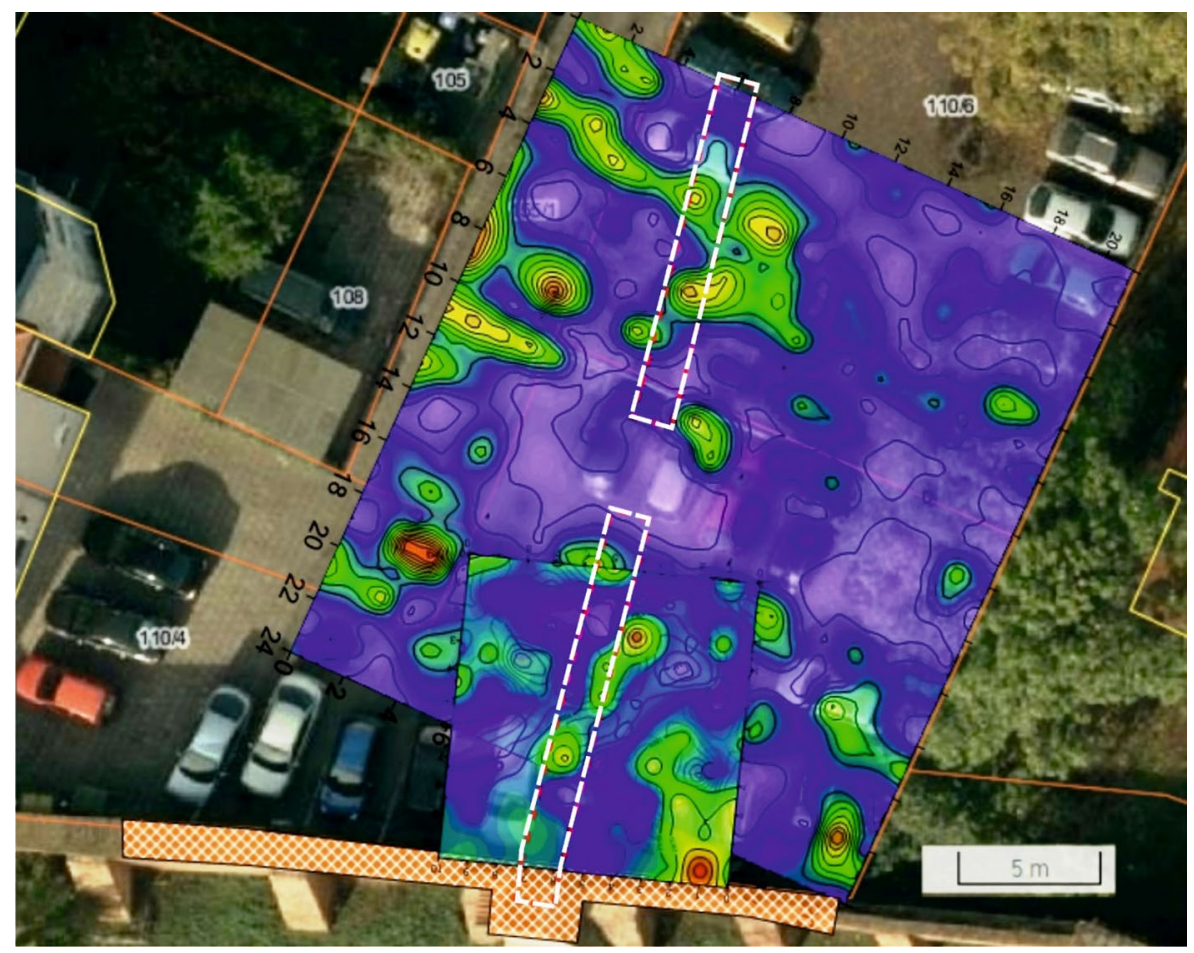

Fig. 12 Map of anomalies detected by the GPR, plotted on a satellite image of the surveyed area. The assumed course of the tunnel is marked by the dashed line 
The water-work (Wasserkunst) in Grudziądz could resemble medieval constructions in Lübeck, Bruges, Hannover, or Bremen. In Lübeck (Germany), the first Brauwasserkunst was constructed as early as in the 1290s. A water wheel driven by the energy of the water flowing in the River Wakenitz set a bucket wheel in motion, which drew water from the river. The water was further distributed through wooden pipes (Grabowski, Mührenberg 1994). In 1283-1284, the construction of a device with a bucket wheel was also known in Bruges (Belgium); there, water was drawn from the urban pond (Sowina 2016). In Hanover (Germany), a device equipped with a bucket wheel was mentioned in 1532; there, water was drawn from the River Leine. When the water level in the river was too low for the wheel to move, the water had to be brought in manually. For this purpose, bailers (buckets) were used. The buckets were attached to the wheel with a chain to be easily removed and reattached (Grewe 2000). A similar solution was probably used in Bremen (Germany) at the end of the fourteenth century. In this case, the device was located at the bridge over the Weser River and equipped with an iron chain wheel (Bischop 2013). In Poland, bucket wheels were used in Kraków and Wrocław (Sowina 2016; Cembrzyński 2011; Grewe 2000). In Grudziądz, a mechanism with a bucket wheel could also be used to raise water from the mill canal, but there is no evidence for or against it. The height difference between the water intake point (mill canal) and the inlet in the city walls was about $12 \mathrm{~m}$, so that it was the height to which the water had to be raised by a bucket wheel.

In the first half of the sixteenth century, suction and lift pumps, called piston pumps, replaced a bucket wheel in the water-works in many European cities, probably also in the water-work in Grudziądz, but it is only speculation. In such water-works, a crankshaft converted the water wheel's rotary motion into a reciprocating motion to move the pistons in the cylinders to pump water uphill. Raising water to the appropriate height by pumps was much more effective than by a bucket wheel. There are many examples of water-works with piston pumps in Europe. For instance, a Wasserkunst equipped with a pump was built in 1523 in Paderborn (Germany), where the water flowing in the River Pader moved the water wheel, which in turn powered the pump. In this way, the water was raised to a height of about $19 \mathrm{~m}$ into a reservoir and then distributed around the town (Grewe 2000). In the water-work in Kraków, suction and lift pumps were in operation as early as 1531, which is confirmed by bills recording the expenditure for the purchase of leather for these pumps (cutes ad pompa) (Sowina 2016). Also in Bautzen (Germany), a water-work equipped with pumps was built in the sixteenth century (Grewe 2000).

In Lübeck, a water-work equipped with pumps was built in 1533 after a 1531 petition by Lübeck merchants, who inhabited the upper part of the town. Interestingly, the new water-work in Lübeck was constructed by Master Claus Moller, native of Hannover. In a high stone tower, there were four piston pumps, which were fed by the River Wakenitz and raised the water through two pipes to a height of $16 \mathrm{~m}$ to the distribution tank. At a similar time, in 1535, a Wasserkunst equipped with as many as six pumps was also constructed in Hannover. The pumps were able to transfer 8000 barrels of water in $24 \mathrm{~h}$; a volume of one barrel was approximately 2001 (Grewe 2000). Thus, it can be speculated that both waterworks, in Lübeck and Hannover, had been constructed according to the design of the same Master.

In Gdańsk, a water-work equipped with suction and lift pumps was designed by Dutch builders and operated at least after 1584. It was a 10-m high brick tower with a hip roof. Inside the tower was a wooden rectangular tank with an open top and a water pumping mechanism. Water was raised into the distribution tank by two piston pumps, which moved alternately, set in motion by a water wheel. At the lower part of the tank, there were three 
pipes going underground to use gravity to distribute water. Excess water was directed by an overflow pipe to the Radunia Channel (Kaczor 2008; Krzywdziński 2008).

Water supply systems consisting of two separate buildings-a water-work with mechanism raising water and a water tower with distribution tank on the top-had been used in Europe since the end of the fifteenth century. The reservoir was always located on top of the water tower independently of mechanisms used to raise water (bucket wheels or pumps). It has been confirmed by studies in many cities in Europe: Prague (on the Vltava River; Czech Republic; end of the fifteenth century), Olomouc (Czech Republic; 1514), Lublin (Poland; first half of the sixteenth century), Płock (Poland; first half of the sixteenth century) and Wrocław (Poland/Silesia; end of the sixteenth century) (Mazurek 1986; Hoczyk-Siwkowa 1997; Cembrzyński 2011; Sowina 2016). The high water-supply tower was usually a part of the urban fortifications so that it could also perform defensive functions, which has been pointed out by Urszula Sowina in her analysis of water-works in Augsburg (Germany) and Bruges (Sowina 2016). The same could be true in Grudziądz, where the water tower adjoined the city walls and was a part of the fortification. The drawing by Dahlberg (Fig. 7) shows the water tower (or water-work) together with the city fortifications during the siege of Grudziądz by the Swedish army in 1656. However, there is lack of information about the role of this building during this battle and state of preservation after the siege.

The water distribution system was an important element of the municipal water supply system. Both historical sources and results of archaeological research indicate that the common practise in Western Europe, as well as in the Kingdom of Poland and the State of the Teutonic Order in Prussia, was to lay the pipes in trenches. Archaeological research conducted in Gdańsk, Elblagg and Torun (Poland) has shown that wooden water supply pipes were connected to each other by means of metal rings, then placed in the trench, sealed at the joints, backfilled with sand and mulch, and finally covered (Woelky and Saage 1860; Czaja and Nawrolski 1993; Nawrolska 2005; Maciakowska 2011; Sowina and Kulczykowski 2017). The less frequently used method was lying the pipes in canals under the streets. These canals, in the form of tunnels, were large enough to move around in and carry out the repair and maintenance works on the water supply network. There are many examples of underground brick water supply tunnels, such as those in Siena, Perugia and Orvieto (Italy) and Exeter (England), as well as those at the early medieval Carolingian Palace in Ingelheim (Germany), and the Cistercian Abbey in Fontenay (France) (Holt 2000; Magnusson and Squatriti 2000; Lohrmann 2013; Benoit and Rouillard 2000; Sowina and Kulczykowski 2017). In Poland, in the area of the former Kingdom of Prussia, in Prabuty, there is a well-preserved tunnel of similar function. It was constructed after the great fire of May 1722 to be also a part of a fire protection system (Schwalm 1896).

In Grudziądz, only a few artefacts related to the old water distribution system were preserved. There are single fragments of wooden pipes, connected with metal fittings found in 1961 and 1974 (Sikorska 1961; Boguwolski 1974), and a brick well at the back of the lot at 18 Szewska Street (Boguwolski 1974-1975) found in 1974 during reconstruction of streets and buildings in the town. The water distribution system was a network of water pipes ending in wells. In flowing wells, there were pipes removing excess water on the opposite side of the well. The water wells were usually barrels without a cover, placed in a wooden box, buried in the ground and covered with sand. The sand between the barrel and the box stabilized the construction and played a filtering role limiting the entry of external pollutants into the well (Cembrzyński 2011). Wooden lining of the wells was above the ground surface and water was drawn up using containers, such as buckets, that were raised mechanically (using a shadoof or reel) or by hand. 


\section{Summary}

In Grudziądz, due to the functioning urban public space and the conservation protection of the area (Old Town), the direct surveys of the ground (excavation, drilling or probing) were not allowed. Therefore, various non-invasive methods, such as the aerial prospection (UAV), LiDAR scanning and geophysical surveys of the ground using GPR were applied. These surveys were carried out in the water supply tower, the only well-preserved artefact of the former Grudziądz waterworks, and its surroundings. This is the first scientific study of this unique hydrotechnical structure. As a result of the research, the inlet to the underground water supply tunnel has been discovered. Furthermore, LiDAR scanning of the exterior and interior of the water supply tower and the area around the tower has given data for digital documentation of the tower and its surroundings, which is useful for further processing and visualization on the basis of GIS software. The analysis of GPR data has not provided conclusive information on the course of the tunnel from the tower towards the centre of Grudziądz Old Town.

The historical analysis, field documentation, LiDAR scanning and geophysical surveys, when taken together, offer an insight into the history of the water supply system in Grudziądz over the centuries and provide useful tips for choosing the particular excavation site. Further research would be required in the area of the lower line of the southern town walls, where the water-work was probably located, as well as in the area of the water supply tower, between two lines of the town walls, where the town pipelines probably ran.

This detailed research on the waterwork in Grudziądz shows how important and useful is to study the urban hydrotechnical infrastructure in the cities of Central and Eastern Europe over the centuries to complete the picture of the development, transfer of technology and similarities of systems in Europe. Until now, this topic has been absent in academic discourse and international scientific literature. I tried to change it.

Acknowledgements This work was supported by the National Science Center, Poland under Grant 2016/23/N/HS3/03168.

Author contributions Not applicable.

Data availability Not applicable.

Code availability Not applicable.

\section{Declarations}

Conflict of interest Not applicable.

Open Access This article is licensed under a Creative Commons Attribution 4.0 International License, which permits use, sharing, adaptation, distribution and reproduction in any medium or format, as long as you give appropriate credit to the original author(s) and the source, provide a link to the Creative Commons licence, and indicate if changes were made. The images or other third party material in this article are included in the article's Creative Commons licence, unless indicated otherwise in a credit line to the material. If material is not included in the article's Creative Commons licence and your intended use is not permitted by statutory regulation or exceeds the permitted use, you will need to obtain permission directly from the copyright holder. To view a copy of this licence, visit http://creativecommons.org/licenses/by/4.0/. 


\section{References}

\section{Archival sources}

Geheimes Staatsarchiv Preußicher Kulturbesitz Berlin Dahlem

GStA PK, XI. HA Karten, Allg. Kartensammlung d. Geheimen Staatsarchivs: D 50440

Kriegsarchiv in Stockholm, ref. SE/KrA/0425/06/010

Riksarkivet Marieberg in Stockholm, ref. SE/RA/720269/\#/0041:00001

Riksarkivet Marieberg in Stockholm, ref. SE/RA/754/2/XV/ /0005:00001

State Archives in Torun, files of the City of Grudziądz, reference number 448

\section{Bibliography}

Baczko L (1800) Reise durch einen Theil Preussens, vol 2. Gottfried Wollmer, Hamburg

Benoit P, Rouillard J (2000a) Medieval hydraulics in France. In: Squatriti P (ed) Working with water in Medieval Europe. Brill, Leiden, pp 161-216

Bischop D (2013) Die Wasserversorgung von Bremen vom Spätmittelalter bis in die Frühe Neuzeit. In: Wiplinger G (ed) Historische Wasserleitungen. Gestern - Heute - Morgen: internationales Symposium mit besonderer Berücksichtigung ihrer denkmalgerechten und betriebssicheren Erhaltung: Wien, 19-23 Oktober 2011. Peeters Publishers, Leuven, pp 205-216

Boguwolski R (1974) Grudziądz-Stare Miasto, ul. Szewska 18. Studnia - dokumentacja. Manuscript in the collections of the Museum in Grudziadz, Grudziądz

Boguwolski R (1974-1975) Grudziądz-Stare Miasto. Dokumentacja opisowa i rysunkowa. Manuscript in the collections of the Museum in Grudziadz, Grudziądz

Cembrzyński P (2011) Zaopatrzenie w wodę i usuwanie nieczystości w miastach stref bałtyckiej i sudeckokarpackiej w XIII-XVI wieku. In: Wratislavia Antiqua series, vol 14. Uniwersytet Wrocławski, Wrocław

Chmielewski E (1999) 100 lat wodociągów miejskich. In: Skowrońska K (ed) Kalendarz Grudziądzki 1999. Grudziądzkie Towarzystwo Kultury, Grudziądz, pp 73-75

Czaja R, Nawrolski T (1993) Kultura. In: Groth A (ed) Historia Elbląga, Part 1, vol 2. MARPRESS, Gdańsk, p 222

Fischer P (1906) Graudenz und Feste Courbiere. Verlag von Arnold Kriedte, Graudenz

Froelich X (1868) Geschichte des Graudenzer Kreises, vol 1. Selbstverlage, Graudenz

Grabowski M, Mührenberg D (1994) In: Lübeck fließt Wasser in Röhren... seit 700 Jahren! Lübecker Nachrichten, Lübeck

Grewe K (2000b) Water technology in Medieval Germany. In: Squatriti P (ed) Working with water in Medieval Europe. Brill, Leiden, pp 129-160

Hoczyk-Siwkowa S (1997) Wodociągi Lubelskie w XV-XVII w. Kwart Hist Kult Mater 45:168-174

Holt R (2000c) Medieval England's water related technologies. In: Squatriti P (ed) Working with water in Medieval Europe. Brill, Leiden, pp 51-100

Kaczor D (2008) Sieć wodociągowa w Gdańsku XVI-XVIII wieku. Aspekty prawne i ekonomiczne. Kwart Hist Kult Mater 56:325-341

Karczewski J (2007) Zarys metody georadarowej. Uczelniane Wydawnictwa Naukowo-Dydaktyczne AGH, Kraków

Kola R, Kotlewski L, Mikulski K (2005a) Źródła pozyskiwania wody i jej wykorzystanie w produkcji rzemiosł toruńskich w XIV-XVIII wieku. In: Fejtová O, Ledvinka V, Pešek J (eds) Documenta Pragensia, vol 24. Scriptorium, Praha, pp 207-215

Krzywdziński R (2008) Zasada działania gdańskiego Wasserkunstu w XVI-XVIII wieku. Kwart Hist Kult Mater 56:343-351

Kurzyńska M (2016) Stan badań archeologicznych średniowiecznego Grudziądza. Rocz Grudziądzki 24:13-35

Lohrmann D (2013) Die große Aquädukte des Mittelalters (12.-13. Jahrhunder). Sevilla, Perugia, Waltham Abbey. In: Wiplinger G (ed) Historische Wasserleitungen. Gestern - Heute - Morgen: internationales Symposium mit besonderer Berücksichtigung ihrer denkmalgerechten und betriebssicheren Erhaltung: Wien, 19-23 Oktober 2011. Peeters Publishers, Leuven, pp 183-194 
Maciakowska Z (2011b) Kształtowanie przestrzeni miejskiej Głównego Miasta w Gdańsku do początku XV wieku. Muzeum Archeologiczne w Gdańsku, Gdańsk

Magnusson R, Squatriti P (2000d) The technologies of water in Medieval Italy. In: Squatriti P (ed) Working with water in Medieval Europe. Brill, Leiden, pp 217-266

Mazurek Z (1986) Technologia wodociaggu staropolskiego miasta Lublina w XVI w. In: Gruba J, Schnejder R (eds) Konferencja naukowo-techniczna nt. Wodociagg staropolski miasta Lublina. Polskie Zrzeszenie Inżynierów i Techników Sanitarnych, Lublin, pp 39-57

Nawrolska G (2005b) Elbląg w XIII wieku w świetle źródeł archeologicznych. In: Leciejewicz L, Rebkowski M (eds) Civitas Cholbergiensis. Transformacja kulturowa w strefie nadbałtyckiej w XIII w. Le Petit cafe, Kołobrzeg, pp 147-169

Previtali M, Valente R (2019) Archaeological documentation and data sharing: digital surveying and open data approach applied to archaeological fieldworks. Virtual Archaeol Rev 10(20):17-27

Schwalm L (1896) Geschichte der Stadt Riesenburg. Louis Schwalm's Verlag, Riesenburg

Sowina U (2016) Water, towns and people. In: Polish lands against a European background until the mid16th century. Peter Lang, Frankfurt am Main

Sowina U, Kulczykowski W (2017) The first urban water supply systems in the State of the Teutonic Knights: the transfer of hydrotechnical knowledge. In: Girsztowt A, Kitowski P, Gierszewski A (eds) Origines et mutationes, Transfer - Exchange - Power. Wydawnictwo Libron, Kraków, pp 51-62

Sikorska B (1961) Z naszego muzeum. Biul Muz Grudziądzu 14:6-7

Wiewióra M (2012) Próba rekonstrukcji etapów budowy i układu przestrzennego zamku. In: Wiewióra M (ed) Zamek w Grudziądzu. Studia i materiały. Drukarnia Abedik, Toruń, pp 359-378

Woelky CP, Saage JM (eds) (1860) Codex diplomaticus Warmiensis, vol 1. Verlag von Franz Kirchheim, Mainz

Publisher's Note Springer Nature remains neutral with regard to jurisdictional claims in published maps and institutional affiliations.

Wacław Kulczykowski received the M.Sc. and Ph.D. in Archaeology from the University of Gdańsk. He currently works at the Faculty of History, University of Gdansk. He is interested in the history of medieval and pre-modern water supply systems in Europe. His work focuses on the urban hydrotechnical infrastructure in the cities of Central and Eastern Europe. He has won the 2016 City of Gdańsk Jan Uphagen Award for Young Scientists in the category of the Humanities and Social Sciences for his "outstanding achievements in the fields of archaeology, revitalisation and recording as well as conserving the cultural antiquities of Pomerania". 